\title{
A Christian Response to the Conflicting Relationship Between Slave and Master in A Christian Household
}

\author{
Investigating Paul's Response to the Conflict Between the Economic \\ Relationship and the Christian brotherhood's relationship in the Letter to \\ Philemon
}

\author{
Alex Hon Ho Ip \\ Professor, Chinese University of Hong Kong \\ alexip@cuhk.edu.hk
}

\begin{abstract}
This paper seeks to investigate Paul's response - based on his theological thoughts on love - on the conflicting relationship between Christian master and slave. With the aid of New Institutional Economics (NIE), two major characteristics of the relationship between a master and slave will be explained, namely objectifying and manipulating the relationship. Then, this paper will try to read Paul's response to the conflicting relationship in the letter to Philemon - how he used different rhetoric to persuade Philemon to change his relationship with his slave in different levels, namely, theological perspective, core values and practical concern.
\end{abstract}

\section{Keywords}

letter to Philemon - Paul - love - Roman slavery - new institutional economics - economic relationship

\section{$1 \quad$ Introduction}

This paper aims first at elucidating the conflicting nature of economic relationship between the Christian slave and master, and then, investigating the responses given by Paul in the letter to Philemon. Many researches have been conducted on the Christian response to religious and social conflicts. However, 
not too have been conducted in biblical studies to investigate the Christian response to conflicts arising from the newly expanded Roman economy. The Roman economy did not only grow in size but created many new forms of relationships driven by economic concerns. ${ }^{1}$ The reasons for the absence of research from an economic perspective are mainly methodological. First, it was because of the methodological debate on whether or not modern economic theory can be applied in ancient economy. The second question concerns which model is applicable and can generate outcomes that are relevant to biblical studies. I am not going to give a detailed explanation of these methodological issues here but just state that the main reason for why the appearance of the New Institutional Economics (NIE) in recent years provided a satisfactory answer to both questions. The NIE does not require any numerical data that is hard to find in the Roman economy and additionally, it does not need to assume the existence of markets as the dominant form of means of resources of allocation. Moreover, since the NIE focusses on analysing economic motive and function of both formal and informal institutions, the outcome of it can help us understand the economic relationship between different parties in the 1st century Roman economy. ${ }^{2}$

Concerning the relationship between Roman household and economics, it can be said that although the social aspects of relationships in a roman household, including husband, wife slaves, children, women, and relatives have been widely studied in classics and comparative studies, the economic aspect of these relationships have long been overlooked. Scholars, including Peter Garnsey and Richard Saller, have been aware of the economic function and the importance of household in the Roman economy but cannot find a suitable theoretical tool to investigate them for two main reasons. The existence of various terms, including Greek oikos, domus and familia, which tries to describe the essences of a "household" reflects the complexity of the reality. ${ }^{3}$ The legal content of patria potestas is surely one of the most important characteristics of a household. The interweaving of legal rules with the social norms determined

1 According to Keith Hopkins, the GDP of Roman empire in early 1st century was quite substantial - estimated to be 1.3 to 1.5 times the minimum subsistence. Keith Hopkins', "Rome, Taxes, Rents, and Trade," in: The Ancient Economy, ed. W. Scheidel, S.V. Reden, New York, 2002, pp. 198-200

2 The full explanation of the methodological issue about the applicability of economic theory to ancient economy can be read in the recent monograph by A. IP, A Socio-Rhetorical Interpretation of the Letter to Philemon in Light of the New Institutional Economics: An Exhortation to Transform a Master-Slave Economic Relationship into a Brotherly Loving Relationship (WUNT 2 444), Tübingen, 2017.

3 C. Osiek, D.L. Balch, Families in the New Testament World, Kentucky, 1997, p. 6. 
the actual relationships in a household. ${ }^{4}$ The multiple functions performed by a household and the existence of blood relationship, kinship and working relationship also blurred us from understanding the true relationships in a household. What is lacking is a framework that can help us understand the economic motives and functions behind all these different institutions. I suggest, in this paper, that economics is a better perspective to understand this interweaving relationship and the NIE framework can help us to reconstruct the relationship from an economic perspective, which will significantly help bridge this missing link. With the help of the NIE, we will try to generate two major economic relationships between masters and slaves in a Roman household.

In the matter of Paul's response to economic relationship, this paper does not assume Paul was interested in economics itself or had any form of formal economic training. Paul's primary interest is still how Christians can live out the Christian values in this world with the conflicting values assumed in his eschatological motif. Paul's concern, as elaborated in third section, is how the Christian identity can be lived out in this eschatological period, what values should be upheld instead of the prevailing values in the Roman slavery and how to practice it in real life, given the institutional constraints. Therefore, Paul's view on economic relationship is the same as the other conflicting relationships, such as relationships driven by Jewish and Roman social values. The purpose of this paper, therefore, is first to elucidate in what sense the economic relationship between the slave and master is in conflict in a Christian household, according to Paul's fundamental theological and ethical thoughts. Finally, I will focus on reading the rhetoric in the letter to Philemon and see what Paul has recommended in the letter in response to the conflicting relationship.

\section{Economic Relationship Between Slave and Master in Light of NIE}

Economic relationship refers to the relational outcomes resulting from both the formal and informal institutions driven by economics concern. ${ }^{5}$ The relational outcomes include the attitude towards slaves in general and the actual practice implemented on slaves and what they reinforce on each other. The following section will investigate how both formal and informal institutions will determine the economic relationship between master and slave in a

4 P. Garnsey, R. Saller, The Roman Empire: Economy, Society and Culture, California, 2015, pp.155-157.

5 Ip, Socio-Rhetorical Interpretation, p. 113 . 
household. There is a fundamental assumption in this paper, i.e., the economic force is strong enough behind the economy to be one of the major determining forces that drive the formation of both formal and informal institutions. ${ }^{6}$ The resulting relationship therefore is a composite outcome of these institutions. These institutions can exert effect on the relationship because they will affect people's attitudes through the daily practices determined by these institutions.

Unlike other classical and neoclassical economic theories, which rely on the assumption of the existence of market and depend very much on the numerical data for their analysis, the NIE focusses on analysing the economic motive and functions of both formal and informal institutions. ${ }^{7}$ Through the analysis of NIE, we can better understand the economic motives of those who have power to determine both formal and informal rules and how, through them, the relational outcome of master and slave is determined. The following section will demonstrate two major characteristics of the economic relationship between the slave and master in light of the NIE analytical framework.

\subsection{Objectifying Relationship}

The first economic relationship presented here is the objectifying relationship. ${ }^{8}$ It is the most representative economic essence of slave. The economic purpose of objectifying is clear, since by objectifying the slave, the master can gain the maximum return from it by using it or selling it. However, why and how can one objectify a slave who is indeed a human being? The reason for objectifying a slave is to make it a product that can be sold. Only a product can generate and store value. Without the possibility of reselling a slave, the master or the owner cannot capitalize the value of a slave but can only use their labour force. Additionally, by objectifying the slave, the master can use them as if they are merely an instrument. This also implies that they can use them in ways that are not humane and unsuitable for human beings since they are not defined as humans any more. Defining the slave as property or merely a tool is the first step to make a human being used and a product to be traded so as to maximize one's possible returns from using and owning a slave. This creates the first con-

6 Ip, Socio-Rhetorical Interpretation, p. 125.

7 B. Chavance, Institutional Economics, New York, 2009, p. 1.

8 The full economic analysis of objectifying a slave in Roman Slavery can be found in Ip, SocioRhetorical Interpretation, p. 142-152. This section will only be a summarized section with the emphasis placed on how the outcome of objectifying relationship may create conflicts in a household. Choosing this economic characteristic to discuss is because this is the most fundamental economic relationship for slave master relationship among all others. 
flict in a Christian household that how to view a slave, supposed to be an instrument, as a brother (Phlm 1:16)?

In light of the NIE framework, we will investigate how the Roman formal and informal institutions facilitate the above-mentioned function. The formal institutions function by giving the ground and legal justification for viewing slaves as tools or property, whereas the informal institution helps provide the necessary moral ground for defining slaves as things in law. The most important step for Romans in defining slaves is to define them as "res" and place them not in the law of persons but in the law of things. In this respect, slaves were classified as res mancipi among various kinds of property that were subjected to the law of property. Legally speaking, slaves were property in the sense that they were under the absolute control of their master and were subject to be transferred from one master to another. As servus communis, they could be owned by multiple owners at the same time as common property. ${ }^{9}$ Slaves were owned by their masters as res mancipi without any legal rights assumed..$^{10}$ They were chattel and could be bought and sold as other properties, and could own nothing by themselves. These legal definitions, formal institution, was the essential grounds for the establishment of other economic relationships. ${ }^{11}$

However, only the formal institution was not enough to explain why the Roman slavery system can be so grand and widely accepted in the empire. It required a belief and value system to sustain or justify the formal definition of the slave. More importantly, there were other values existing in the Roman society, that are conflicting with other fundamental values of the society, with the purpose of supporting the formal institutional of slavery.. The Roman society placed personal freedom as a very important social value. How can Romans emphasize on individual freedom on the one hand and define human being as property on the other hand? The informal institution mainly functions to provide a moral justification to sustain the formal institution. One of the most influential informal institution is the natural slave theory suggested by Aristotle which was still prevailing in first century. Aristotle defined a slave as follows: "one who is a human being belonging by nature not to himself but to another is by nature a slave, and a person is a human belonging to another if being a man he is an article of property, and an article of property is an instru-

9 A. Berger, Encyclopedic Dictionary of Roman Law, Philadelphia, 1953, p. 704.

10 Res mancipi refers to the type of property that required a formal way of conveyancing, including mancipatio and cessio. P.D. Plessis, Borkowski's Textbook on Roman Law, Oxford, 2010, p. 88. 
ment for action separable from its power."12 This definition provides the philosophical justification that it is natural to have two group of people, one to manage and the other to be managed. The resulting attitude and values towards slave, generated by both formal and informal institutions, definitely contradicted to the concept of Christian brotherhood which viewed everyone is the same in Christ.

\subsection{Manipulating Relationship}

The second economic relationship is called manipulating relationship. ${ }^{13}$ It refers to the way and underlying motives behind giving certain room for humanity towards slaves are mainly driven by the masters' self-interest in the economic concern, which is in conflict with the fundamental Christian teaching of "loving your neighbour as yourself." To show that the relationship was manipulative, I will explain how the slave masters did not genuinely recognize the human nature of slaves but aimed only at stimulating their productivity to the highest. Although it is clear that slaves were not recognized as humans and lacked the legal right to protect themselves, it would be wrong to conclude that slaves were merely treated as a "thing" in reality. ${ }^{14}$ However, it is a misconception that slaves were defined merely as res ("thing") in the Roman law and then, were managed, without the help of other institutions, as things. The main reason is that their major source of productivity comes from, ironically, their human nature, which the legal definition tries to deny. In fact, as pointed out by William Buckland, the Roman law did recognize the different perspectives of the humanity of slaves. ${ }^{15}$ Additionally, there were many Roman laws that recognized a slave's personality and gave him or her a certain number of rights. ${ }^{16}$ For example, slaves could hold de facto property called peculium and were allowed to have quasi-marital relationships. ${ }^{17}$ So the question here is for what reason did the Romans recognize the slaves' personality? David Johnston is right to point out that although slaves were primarily treated as property, they

12 Aristotle, Politics, Cambridge, 1959, p. 19.

13 The full economic analysis of manipulating relationship can be found in Ip, Socio-Rhetorical Interpretation, p. 153-176. This summarized sections aims at showing the conflicts created by the major manipulating polices. The reason for choosing this economic relationship for discussion because it explains the economic motives of some of the major policies of Roman slavery.

W.W. Buckland, The Roman Law of Slavery: The Condition of the Slave in Private Law from Augustus to Justinian, New York, 1970, p. 2.

15 Ibid., 4.

16 D. Johnston, Roman Law in Context, Cambridge, 2004, p. 43.

17 Ibid., 43 . 
were also perceived as humans, so that their human characteristics, such as their intellectual abilities, could be used. ${ }^{18}$

In terms of the NIE, the informal institutions for manipulating relationships is a kind of contractual arrangement. Contractual arrangement concerns how slaves were managed in practice based on the formal institution and other informal institutions. At first glance, it may seem to be contradictory for Roman slavery to allow manumission for slaves. From the perspective of the NIE, the existence of this kind of contractual arrangements mainly serves managerial purposes given that the cost of managing slaves is very high. The following section will focus on one of the typical examples, manumission. Manumission was indeed a very complicated contractual arrangement. Masters could only allow some of the slaves to be freed. There were different kinds and levels of manumission, and slaves had to save up their own peculium to pay for their own freedom. Manumission served as the ultimate possible reward for those who did their roles well. ${ }^{19}$ Why did slave masters need to create that fake hope? What was the economic reason behind it? It was because slaves had been involved in various jobs in one's household, business and trade. Their loyalty was essentially important because slaves had been involved in jobs that required their professional knowledge, decision making ability, and sometimes they even represented their master in long distance trade, and at the same time, it involved very high costs for the master to monitor their performance. So, how could the slaves be kept loyal? And how could the master manage to get the highest productivity from slaves? It could not mainly rely on punishment, which obviously set the basis of the whole slavery. They set up these fake hopes (of Manumission) and fake assets (of peculium) to create opportunity cost for betrayal. Without these, these slaves will have nothing to lose to betray or even hurt their master to get their freedom. In Paul's letters, he emphasized two times, in Rom. 13:8 and Gal. 5:14, that commandment can be summarized as "love your neighbour as yourself." Therefore, such kind of fake hope created aiming at getting the highest possible benefit for slave master surely is in conflict with the loving relationship between brother and sister in Christ.

\section{$3 \quad$ Christian Response to Conflicting Relationships}

A Christian response does not only mean what to do but include the theological perspective, core values and practical concern. The following analysis will

\footnotetext{
18 Ibid., 42.

19 To understand the complicated nature of manumission and their economic functions, see Ip, A Socio-Rhetorical Interpretation, pp. 169-171.
} 
focus on analysing these three perspectives in the letter to Philemon (Phlm). The Phlm is not a letter written to ask for forgiveness of a runaway slave but to ask for a transformation of relationship from the economic driven relationship to a loving brotherhood relationship. ${ }^{20}$ This section will focus on reading Paul's response to the economic relationship in Phlm where he tried to persuade Philemon to accept Onesimus as a beloved brother. By reading Paul's rhetoric in Phlm, we will generate three implied major responses. These three responses do not include all the messages in Phlm but represent the key structure of Paul's view of the Christian response to the conflicting economic relationship. The first response is Paul's eschatological view, which is the ground for Paul's ethical teaching. It answered the basic question of what the Christian identity is in this sinful world. The second response was the key value to be upheld in light of the conflicting values implied in the economic relationship between the Roman slave and master. Finally, it concerned how the loving value could

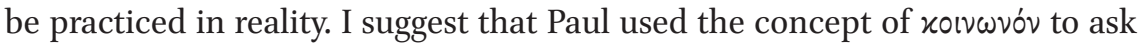
Philemon to think creatively on how the loving relationship could be practiced in light of the existing manipulating institutions.

\subsection{Theological Perspective: Eschatological Motif in This World}

Eschatological motif is a lens to read Paul's ethical teaching. It tells us about Paul's fundamental view on Christian living in this world after their conversion, which is the foundation for understanding Paul's ethical teaching. According to Furnish, the eschatological motif of Paul has two important dimensions. The first is the present dimension. God's transcendent power has already been present in this age. The salvation has come through the death and resurrection of his Son (Gal 1:3-4), which in turn has two senses: negative and positive. Negatively, it releases man from the bondage of sin. Positively, it transforms man into a totally new creation (2 Cor 5:17). ${ }^{21}$ Therefore, the conflict between the economic relationship and the loving brotherhood relationship implies a conflicting value of this age with the values of the ages to come.

Given the eschatological motif, believers have a new identity as a radical creation of God situated in this age. Paul reminds believers in Philippians that they have a new citizenship (Phil 3:21) who are still living in this age. The implication is that Paul's teaching does not place his hope in the present system. Based on the same eschatological view, the fundamental thought in the letter to Philemon is to ask Philemon to exercise his freedom to love in contrast to values implied in the Roman slavery. Paul's response did not rely on a change in the worldly institutions as he understood well the evilness of this age and

\footnotetext{
20 Ip, A Socio-Rhetorical Interpretation, pp. 187-188.

21 Victor P. Furnish, Theology and Ethics in Paul, Kentucky, 2009, pp. 122-23.
} 
did not place hope on this age. However, Paul believed that, because of love, we have our mission as a new creation in this eschatological moment.

Love is the core value of the Christian identity and the loving relationship represents the essence of a believing community. In Philemon, verse 8-9 clearly indicates Paul's eschatological purpose: To instil a new value that transcended the prevailing values such as objectifying and manipulating. Paul begins his

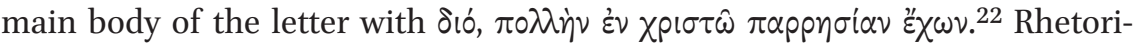
cally, Paul says in verse 8-9 that "he is bold in Christ to order Philemon to do the right thing, but finally choose to appeal to him based on love." There is a clear eschatological intention in these two verses. First, Paul implied that, since he says he is bold to order Philemon to do the right thing, he understood well the rationale behind a master to exercise his power given by both the formal and informal institutions. However, he rhetorically teaches and demonstrates, by his own action implied in verses 8-9, that choosing to love has a higher priority than other worldly prevailing values and power. His action in the speech shows that he does not only believe that love is the eschatological new value but act out the "newness" of it by forgoing the power he can use. The rhetorical power of these two verses, therefore, not only lies in establishing love as the ground value for one's action, but also in challenging Philemon to make a choice between what he may have thought as being right and love. ${ }^{23}$

\subsection{Core Value: Loving Attitude Replaces the Objectifying Value}

The new identity in Christ and the new loving relationship with others is totally against the objectifying attitude towards slaves. Therefore, Paul places strong emphasis in arguing against the objectifying attitude and arguing for a loving brotherly relationship in the Phlm. Norman Petersen conducted a survey of words related to the different types of "relationships" by Paul in the letter and put them into different categories for analysis. ${ }^{24}$ Fourteen, out of the twenty-five, verses contain relational words. Some verses have more than one relational word. Besides, Paul is arguing step by step until the climax of his request in verse 16. Starting from verse 10, the first time Paul called Onesimus, he calls Onesimus "his child," which is against the legal definition where a slave is

22 Stanley B. Marrow suggested that the word in political use means the freedom of speaking in the $\varepsilon \varkappa \varkappa \lambda \eta \sigma i \alpha$ because of one's full Greek citizenship. Douglas Moo similarly suggested that the understanding of $\pi \alpha \rho \alpha \dot{x} \lambda \eta \sigma \omega$ as "boldness" has morphed from its use as "openness" as gospel writers used it to describe Jesus and his followers "openly" proclaiming God's Word to the world. This openness referred to the rights of the people to freely express their opinions in a democracy.

23 Ip, A Socio-Rhetorical Interpretation, pp. 194-195.

24 N.R. Petersen, Rediscovering Paul: Philemon and the Sociology of Paul's Narrative World, Philadelphia, 1985, pp. 90-93. 
considered as a thing or a general perception of the slave as a walking tool. He further emphasized the human nature of Onesimus in verse 11 by saying that he was "my own heart". What is the reason for Paul to argue for a loving relationship in such a rhetorical way? Why didn't Paul just instruct Philemon to act according to what he was supposed to act?

This is one of the major characteristics of economic relationship whose impact was deeper than one may have previously thought. Objectification of slaves was not only stated in the law and justified by various informal institutions. The relationship was the result of being practiced every day, and therefore, deeply implanted in the slave masters' value system. Therefore, objectifying a slave was not merely a nominal relationship but a deeply rooted one between the master and slave. ${ }^{25}$ This may be one of the reasons why Paul does not choose to use merely instruction to instruct Philemon not to treat Onesimus as a slave but ends up using such refined rhetoric to persuade Philemon to accept that change of new value, as one of the main functions of rhetoric is to lead the audiences to "see" what they cannot see in their original position. ${ }^{26}$ Based on the loving relationship, which is the fundamental value in Phlm, we have a new relationship with God and a new relationship with our believing community.

\subsection{Practical Concern: A Partnership Replaces the Manipulating and Exploiting Relationship}

The third response recommended by Paul is a kind of creative working relationship given the eschatological tension existed. The tension comes from the reality that Philemon cannot simply cut off his relationship with Onesimus as it may imply that he found no other self-sustainable job given the nature of Roman economy. So how could Philemon retain Onesimus's job but get rid of the manipulating relationship? In the original working relationship, the master saw and treated slaves as an instrument for their own economic benefit. Slaves were merely tools that generate economic benefit for their masters. Those apparent humane policies were for the purpose of generating higher economic returns. In light of this tension, I argue that, in Phlm 17, Paul uses his

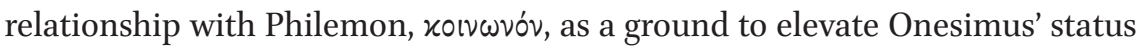
and ask for another specific form of working relationship against the manipu-

25 Ip, A Socio-Rhetorical Interpretation, p. 189.

26 Lynn R. Huber, "Knowing is Seeing: Theories of Metaphor Ancient, Medieval and Modern," in Foundations for Sociorhetorical Exploration: A Rhetoric of Religious Antiquity Reader, ed. Vernon K. Robbins, Robert H. von Thaden Jr., and Bart B. Bruehler, Atlanta, 2016, p. 240. 


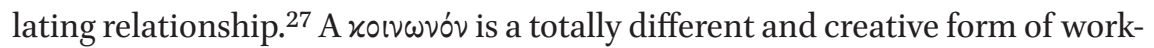
ing relationship from the master-slave relationship. ${ }^{28}$ Consistent with his own eschatological motif, under the Roman economic system, Onesimus may have to work under Philemon either as a slave or freedman in order to earn one's living. Therefore, Paul had to suggest a creative way consistent with the love and eschatological motif, which is a new practical form of loving relationship, for Philemon to choose. ${ }^{29}$ If Philemon really accepted Paul's request (in verse 17) to receive Onesimus as Paul - whom Philemon considered a partner - then the phrase suggests a new working relationship for Onesimus. ${ }^{30}$

Although Paul does not suggest a concrete way for Philemon, the creative

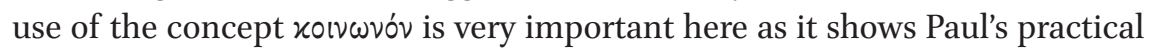
concern. He did consider the feasibility of his suggestion and made corresponding advice. His practical concern extends to verse 18-19. To accept Onesimus as Paul in the new working relationship involved a cost. It implied that Philemon could not exploit Onesimus as other masters did. He might need to provide more genuine humane treatments to him or forgo Onesimus' previous mistakes or unsatisfactory performance. The rhetoric in verses 18 and 19, em-

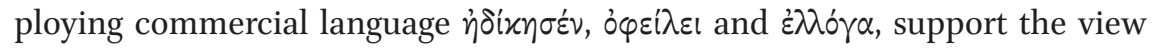
that Paul is dealing with the ultimate economic concern of Philemon if he seriously considered Paul's advice. ${ }^{31}$

\section{4}

\section{Conclusion}

Economics was one of the major determining factors affect the relationship between master and slave. However, the economic perspective has been overlooked in previous scholarship. With the aid of NIE, we can see that economic concern did exert influence on the relationship between slave and master.

27 James Dunn, The Epsitles to the Colossians and Philemon: A Commentary on the Greek Text, Grand Rapids, 1996, p. 338.

28 Julien M. Ogereau, Paul's Koinonia with the Philippains (wUNT2 377), Tübingen, 2014, p. 157-168. Julien quoted many documentary sources to justify the economic connotation of xolvwvós.

29 C.S. De Vos, "Once a Slave, Always a Slave? Slavery, Manumission and Relational Patterns in Paul's Letter to Philemon," JSNT, 82 (2001), p. 102.

30 N.T. Wright, Paul and the Faithfulness of God 1, London, 2013, p. 20. This view also shared by N.T. Wright that it conformed to Paul's theological use of xolv $\omega v 1 \alpha$ as Paul usually uses it to request for reconciliation among people from different races, social statuses and religious concerns. Ip, A Socio-Rhetorical Interpretation, p. 211.

$3^{1} \quad$ Ip, A Socio-Rhetorical Interpretation, pp. 213-215. 
With this economic perspective in mind, we have a new view to understand the possible conflict in a Christian household and how to read Paul's response to such conflicting relationship in Phlm. The response implied in the rhetoric of Phlm is not simply what to do but involves the eschatological view, new values and creative way of practice. 